\title{
The question of the ergonomic use of virtual models
}

\author{
Castañon, J.A.B., Saraiva, T.S., Araujo, T.T. \\ Department of Transport, Federal University of Juiz de Fora, Engineering Faculty, Room 4156 Campu of UFJF, \\ Juiz de Fora, Minas Gerais, Brasil
}

\begin{abstract}
The comfort and functionality between man and his surroundings are the main goals of ergonomics, making it are increasingly in the production process. Many companies have tried Virtual Reality Center (VRC) to assist the analysis and development of ergonomic products. The use of virtual models brings many benefits to the design of products, including greater flexibility, speed and quality, and facilitates the control and reporting, also integrating all stages of the project. There are still some difficulties for the deployment of these resources, like the need for more powerful computers and specialized professionals. Possibly, the VR will be indispensable to the construction in some years, becoming a tool of fundamental importance to the professionals.
\end{abstract}

Keywords: ergonomics, virtual reality, prototype.

Ergonomics is a science that aims to improve the relation of comfort and efficiency between men and his environment. That is being more and more inserted among production process, such as several companies are investing in high technology such as Virtual Reality Center (VRC), which simulates future activities and develop new products. There are many industries that are using the VRC to help to develop products and ergonomic analysis, like some aviation and automotive industries [5].

The virtual models are primarily aimed at impro ving the understanding of what is being proposed for the end result meets the human needs and capabilities; to expose the idea clearly. The use of virtual models also reduces the need for physical production of the models, the time spent on project design and cost of prototype fabrication [5].

Interconnected to ergonomics, the design is presented as a line of work that has fueled the relationship between users and environments. The design is creative and interdisciplinary activity, which aims to meet the esthetic aspects, the relationship with the customer interface and ergonomics, using the modern techniques for solving design problems. The interaction with the ergonomic design results in the improvement of interdisciplinary technology to be able to create new products that suit most users, making it more satisfying and pleasurable [5].

Until recently, all professionals who is involved with the project had to be present at the same place to get the best solutions for the project. But now, with the help of computational resources including computer graphics and virtual reality, these problems are being reduced, giving more flexibility and clarity to the projects, and facilitate the simultaneous use of them [1].

Design professionals have always tried to represent as clearly as possible their projects, representing two-dimensional shape information. On the other hand, in design offices, the use of Information Technology (IT) brings a number of benefits and can improve control and reporting, competitiveness, quality and speed of work. There are, however, several difficulties for the deployment of these resources [2].

Virtual Reality (VR) brings many benefits, both in the design phase and implementation. With VR, is possible to share and test ideas within a real-time project integrating all design processes, and increase quality. Some factors still hinder the application of VR, as the need for more powerful computers and specialized professionals. Probably in some years, Virtual Reality will be a tool of great importance for the construction, but it is essential to disseminate 
those concepts among professionals in this area, as well as the development of technologies, software and hardware, making VR accessible [1].

In Brazil, that is still not a common practice to provide prototypes standard objects used in buildings. It hinders the work of designers prevents a more accurate and complete results of the projects done. The area of architecture, engineering and construction (AEC) has a technology called aided by BIM (Building Information Modeling) or Information Modeling for Construction [3].

The virtual models can contribute to ergonomics as the visualization of virtual models allows a greater understanding of what is being proposed by professionals. These are the use of virtual reality, an important tool that meets the requirements of ergonomics (Figure 1).

(Fonte: http://buildipedia.com/)

Figure 1 - Virtual Reality in ergonomic

\section{References}

[1] L. M. Grilo, S. Monice., E. T. Santos, S. Melhado, Possibilidades de aplicação e limitações da realidade virtual na arquitetura e na construção civil. Simpósio Brasileiro de Gestão da Qualidade e Organização do Trabalho SIBRAGEQ, 2.: anais (CD-ROM). Fortaleza, 03 a 07 /setembro/2001.

[2] M. A. H. Cintra, Uma proposta de estrutura para organização do conhecimento em empresas de edificações. 2005. 190f Tese (Doutorado em Ciências em Engenharia de Produção) COPPE, Universidade Federal do Rio de Janeiro, Rio de Janeiro, 2005 .

[3] M. A. S. Hippert; T. T. Araujo, BIM na pequena empresa de projeto: um estudo de caso. In: Encontro Tecnológico da Engenharia Civil e Arquitetura, 2009, Maringa. VII Encontro Tecnologico da Engenharia Civil e Arquitetura. Maringá : UEM/DEC, 2009.

[4] M. H. Monteiro, M. L. Malard, R. P. Santiago, The implications of Virtual Reality project practices: ergonomic aspects of interactive virtual immersive environments. In: 14 Convención Cientifica de Ingenieria y Arquitectura - XII Congresso Internacional de Grafica Digital,SIGRADI 2008, 2008, Havana. 14 Convención Cientifica de Ingenieria y Arquitectura. Havana : Ministerio de Educación Superior, 2008. v. 1. p. 1-3

[5] R. Gasperini, Realidade virtual aplicada à ergonomia por meio do design participativo. 2010 120f. Dissertação (Mestrado em Design) - Faculdade de Arquitetura, Artes e Comunicação da Universidade Estadual Paulista "Julio de Mesquita Filho", campus de Bauru, Bauru, 2010. 